\title{
Hubungan Tingkat Kecemasan Dengan Kualitas Tidur Penderita Asma Bronkhial di Instalasi Rawat Inap RSUD Kabupaten Bintan \\ Tahun 2019
}

\author{
Meita Witri Artaty \\ Program Studi Ilmu Keperawatan, STIKes Awal Bros Batam \\ Email : meitawitri6@gmail.com
}

\begin{abstract}
ABSTRAK
Menurut data RSUD Kabupaten Bintan, asma merupakan penyakit 10 terbesar dan berada pada peringkat ke-tiga. Dari sepuluh orang penderita asma bronkial diadapatkan enam orang penderita asma bronkhial cenderung memiliki masalah gangguan kecemasan dikarenakan takut sesak kambuh sehingga menimbulkan kematian sehingga dapat tidur hanya dua jam, dua orang penderita asma bronkhial mengatakan bahwa mereka takut dan khawatir yang berlebihan yang sering mereka alami dikarenakan oleh sesak yang sering kambuh dan takut akan mengakibatkan kematian dan hanya dapat tidur satu jam, tiga orang mengatakan bahwa karena nyeri yang dirasakan pada saat serangan asma sehingga dapat tidur hanya satu jam, sedangkan satu orang mengatakan tidak mengetahui penyebabnya dan dapat tidur hanya dua jam. Penelitian ini bertujuan untuk mengetahui hubungan tingkat kecemasan dengan kualitas tidur penderita asma bronkhial di Instalasi Rawat Inap RSUD Kabupaten Bintan Tahun 2019 pada 02 Februari 2020 sampai dengan 02 Maret 2020. Rancangan penelitian ini adalah deskriptif kuantitatif dengan pendekatan cross sectional dengan metode pengambilan sampel dalam penelitian ini adalah total sampling. Sampel dalam penelitian ini terdiri dari pasien asma bronkial di Instalasi Rawat Inap berjumlah 70 orang dan data dianalisa menggunakan uji chi-square. Hasil diketahui bahwa ada perbedaan proporsi kualitas tidur responden yang mengalami tingkat kecemasan ringan dengan yang mengalami tingkat kecemasan sedang, menunjukkan ada hubungan tingkat kecemasan dengan kualitas tidur penderita asma bronchial di Instalasi Rawat Inap RSUD Kabupaten Bintan Tahun 2019. Bagai pelayanan keperawatan penelitian ini tidak hanya berfokus bagi pelayanan farmakologis, melainkan dapat mengembangkan lingkungan yang nyaman.
\end{abstract}

Kata Kunci : Tingkat Kecemasan, Kualitas Tidur

Daftar Pustaka : 43 (2015-2019) 


\title{
The Relationship between Anxiety Level and Sleep Quality of Bronchial Asthma Patients in Inpatient Installation of Bintan District Hospital 2019
}

\begin{abstract}
According to data from the Bintan District Hospital, asthma is the 10th largest disease and is ranked third. Of the ten bronchial asthma sufferers, six bronchial asthma sufferers tend to have anxiety disorders due to fear of recurrence, causing death so they can sleep for only two hours, two bronchial asthma sufferers say that they are afraid and excessive worry that they often experience due to shortness that often recurs and fear will result in death and can only sleep for one hour, three people said that because of the pain felt during an asthma attack so that they could sleep for only one hour, while one person said he did not know the cause and could sleep for only two hours. This study aims to determine the relationship of anxiety levels with sleep quality of bronchial asthma sufferers in the Inpatient Installation of Bintan District Hospital in 2019 on February 2, 2020 until March 2, 2020. The design of this study was quantitative descriptive with cross sectional approach with the sampling method in this study. is total sampling. The sample in this study consisted of bronchial asthma patients in the Inpatient Installation totaling 70 people and the data were analyzed using the chi-square test. The results are known that there are differences in the proportion of sleep quality of respondents who experience mild anxiety levels with those who experience moderate anxiety levels, showing there is a relationship of anxiety levels with sleep quality of bronchial asthma sufferers in the Inpatient Installation of Bintan District Hospital in 2019. As a nursing service, this research is not only focused for pharmacological services, but can develop a comfortable environment.
\end{abstract}

Keywords : Anxiety Level, Sleep Quality

Bibliography : 43 (2015-2019)

\section{PENDAHULUAN}

Asma merupakan penyakit jalan napas obstructive intermitten yang bersifat reversibel ditandai dengan adanya penyempitan jalan napas disertai peradangan dan hiperresponsivitas terhadap stimulus (Rosyidah, 2016). Penyakit ini ditandai dengan riwayat gejala saluran napas berupa wheezing, sesak napas, dada terasa berat dan batuk produktif terutama pada malam hari. Asma tidak memiliki gejala menetap, namun dapat mengalami eksaserbasi dengan gejala ringan sampai berat bahkan menimbulkan kematian. Eksaserbasi asma merupakan peningkatan progresif dari gejala sesak napas, batuk, wheezing, dada terasa berat, dan penurunan progresif dari fungsi paru (Global Initiative for Asthma, 2018).

Kualias Tidur yang tidak adekuat dan dapat mengakibatkan gangguan keseimbangan fisiologi dan psikologi. Dampak fisiologi meliputi penurunan aktivitas seharihari, rasa lelah, lemah, daya tahan 
tubuh menurun dan ketidakstabilan tanda-tanda vital. Dampak psikologis meliputi depresi, cemas dan tidak konsentrasi (Schroeder, 2015).

Berdasarkan

penelitian

Purwaningsih (2014) mengatakan bahwa terlihat perbedaan angka penderita asma tidak tekontrol memiliki kualitas tidur buruk yaitu sebesar 14 responden $(38,9 \%)$ dan enam responden $(16,7 \%)$ memiliki kualitas tidur baik, asma terkontrol sebagian yang memiliki kualitas tidur buruk enam responden $(16,7 \%)$ dan lima responden $(13,8 \%)$ meliliki kualitas tidur baik, pada asma terkontrol penuh satu responden $(2,8 \%)$ memiliki kualitas tidur buruk dan empat responden $(11,1 \%)$ memiliki kualitas tidur baik. Menurut penelitian Witriya (2016) bahwa sebagian besar $(62,3 \%)$ tingkat kecemasan responden masuk kategori sangat ringan sebanyak 33 orang. Sebagian besar $(58,5 \%)$ pola tidur responden masuk kategori baik sebanyak 31 orang.

Data dari catatan rekam medis RSUD Kabupaten Bintan asma merupakan penyakit 10 terbesar dan berada pada peringkat ke-tiga. Selain itu pada bulan agustus 2019 pasien masuk di IGD dengan asma sebanyak 51 orang sedangkan pada bulan Juli 2019 sebanyak 75 orang. Hal ini mengalami penurunan sebanyak 24 orang. Berdasarkan data Rawat Inap RSUD Kabupaten Bintan dari bulan januari sampai dengan Desember 2018 sebanyak 120 orang dengan asma bronkial. Sedangkan pada tahun 2019 dari bulan Januari sampai dengan September sebanyak 235 orang dengan asma bronkial.

$$
\text { Berdasarkan studi }
$$

pendahuluan peneliti dari sepuluh orang penderita asma bronkial menemukan bahwa enam orang penderita asma bronkhial cenderung memiliki masalah gangguan kecemasan dikarenakan takut sesak kambuh sehingga menimbulkan kematian sehingga dapat tidur hanya dua jam. Menurut dua orang penderita asma bronkhial mengatakan bahwa mereka takut dan khawatir yang berlebihan yang sering mereka alami dikarenakan oleh sesak yang sering kambuh dan takut akan mengakibatkan kematian dan hanya dapat tidur satu jam. Menurut tiga orang mengatakan bahwa karena nyeri yang dirasakan pada saat serangan asma sehingga dapat tidur hanya satu jam, sedangkan satu orang mengatakan tidak mengetahui penyebabnya dan dapat tidur hanya dua jam. Mereka merasa cemas dengan keadaan yang mereka alami. Mereka mengeluhkan cemas dan takut pada saat terjadi serangan asma dan mengakibatkan kematian, sehingga dengan kondisi itu kualitas tidur penderita asma tidak terpenuhi secara optimal

Berdasarkan latar belakang diatas, maka peneliti tertarik untuk melakukan penelitian tentang "Hubungan Tingkat Kecemasan Dengan Kualitas Tidur Penderita Asma Bronkhial di Instalasi Rawat Inap RSUD Kabupaten Bintan Tahun 2019".

\section{METODELOGI PENELITIAN}

Jenis penelitian yang digunakan pada penelitian ini adalah deskriptif kuantitatif dengan pendekatan cross sectional. 
Penelitian ini bertujuan untuk menganalisa hubungan tingkat kecemasan dengan kualitas tidur penderita asma bronkhial di Instalasi Rawat Inap RSUD Kabupaten Bintan. Pada penelitian ini sebagai populasinya adalah seluruh pasien asma bronkial di Intalasi Rawat Inap di RSUD Kabupaten Bintan dalam kurun waktu 1 bulan yang rataratanya 70 pasien. Pada penelitian ini, peneliti menggunakan teknik sampel jenuh atau total sampling yaitu teknik penentuan sampel dengan cara mengambil seluruh anggota populasi sebagai responden atau sampel yaitu 70 orang.

\section{HASIL PENELITIAN}

Berdasarkan hasil penelitian, diperoleh karakteristik responden yang meliputi umur, pendidikan terakhir, dan pekerjaan dapat dilihat pada tabel dibawah ini:

\section{Karakteristik Responden}

Tabel 4.1 Karakteristik Responden di Instalasi Rawat Inap RSUD Kabupaten Bintan

\begin{tabular}{clcc}
\hline NO & $\begin{array}{c}\text { Karakteristik } \\
\text { Responden }\end{array}$ & f & \% \\
\hline 1 & Usia & & \\
& a. $\quad<20$ Tahun & 2 & 2,9 \\
& b. $\quad 20-40$ Tahun & 4 & 5,7 \\
& c. >40 Tahun & 64 & 91,4 \\
& $\quad$ Total & $\mathbf{7 0}$ & $\mathbf{1 0 0}$ \\
2 & Jenis Kelamin & & \\
& a. Laki-Laki & 34 & 48,6 \\
& b. Perempuan & 36 & 51,4 \\
& $\quad$ Total & $\mathbf{7 0}$ & $\mathbf{1 0 0}$ \\
& Kelas Rawat & & \\
& a. I & 7 & 10 \\
& b. II & 42 & 60 \\
& c. III & 21 & 30 \\
& Total & $\mathbf{7 0}$ & $\mathbf{1 0 0}$ \\
\hline
\end{tabular}

Berdasarkan tabel $4.1 \mathrm{di}$ atas dapat dilihat bahwa responden yang dilakukan wawancara sebanyak 70 orang. Usia responden adalah yang berusia lebih dari 40 tahun. Dengan responden tertinggi adalah laki-laki dengan jumlah 36 orang $(51,4 \%)$. Dalam penelitian ini, kelas rawat inap responden tertinggi adalah kelas II dengan kumulatif sebanyak 42 responden $(60 \%)$.

\section{ANALISA UNIVARIAT}

Tabel 4.2 Distribusi Frekuensi Tingkat Kecemasan Responden di Instalasi Rawat Inap RSUD Kabupaten Bintan Tahun 2019

\begin{tabular}{clc|c} 
No & Kecemasan & f & \% \\
\hline 1. & Ringan & 38 & 54,3 \\
\hline 2. & Sedang & 32 & 45,7 \\
\hline & Jumlah & $\mathbf{7 0}$ & $\mathbf{1 0 0}$ \\
\hline
\end{tabular}

Berdasarkan Tabel 4.2. diatas dapat dilihat bahwa tingkat kecemasan responden di Instalasi Rawat inap RSUD Kabupaten Bintan tertinggi yaitu tingkat kecemasan ringan sebanyak 38 orang $(54,3 \%)$ dan terendah yaitu kecemasan sedang adalah 32 orang $(45,7 \%)$.

Tabel 4.3 Distribusi Frekuensi Kualitas Tidur Responden di Instalasi Rawat Inap RSUD Kabupaten Bintan Tahun 2019.

\begin{tabular}{ccc|c} 
No & $\begin{array}{c}\text { Kualitas } \\
\text { Tidur }\end{array}$ & f & \% \\
\hline 1 & Baik & 40 & 57,1 \\
\hline 2 & Buruk & 30 & 42,9 \\
\hline & Jumlah & $\mathbf{7 0}$ & $\mathbf{1 0 0}$ \\
\hline Berdasarkan & Tabel & 4.3 & diatas
\end{tabular}
dapat dilihat bahwa kualitas tidur responden di Instalasi Rawat inap RSUD Kabupaten Bintan tertinggi yaitu kulaitas tidur baik sebanyak 40 orang $(57,1 \%)$ dan terendah yaitu buruk adalah 30 orang (42,9\%). 
Hubungan tingkat kecemasan dengan kualitas tidur penderita asma bronchial dapat dilihat pada tabel dibawah ini:

Tabel 4.4 Hubungan Tingkat Kecemasan Dengan Kualitas Tidur Penderita Asma Bronkhial Di Instalasi Rawat Inap RSUD Kabupaten Bintan Tahun 2019

\begin{tabular}{llrrrrrrr}
\hline \multirow{2}{*}{ No } & \multirow{2}{*}{ Kecemasan } & \multicolumn{4}{c}{ Kualitas Tidur } & \multirow{2}{*}{ Jumlah } & Nilai \\
\cline { 3 - 6 } & & \multicolumn{2}{c}{ Baik } & \multicolumn{2}{c}{ Buruk } & & & P value \\
& & $\mathrm{n}$ & $\%$ & $\mathrm{n}$ & $\%$ & $\mathrm{n}$ & $\%$ & \\
\hline 1. & Ringan & 30 & 75 & 8 & 26,7 & 38 & 54,3 & 0,000 \\
\hline 2. & Sedang & 10 & 25 & 22 & 73,3 & 32 & 45,7 & \\
\hline & Jumlah & 40 & 57,1 & 30 & 42,9 & 70 & 100 & \\
\hline
\end{tabular}

Berdasarkan tabel 4.4 dapat diketahui bahwa dari 70 responden sebagian besar responden tingkat kecemasan ringan kualitas tidur baik ada $75 \%$, hanya 26,7 yang kualitas tidurnya buruk dan sebagian besar responden tingkat kecemasan sedang kualitas tidurnya buruk ada 73,3\%, hanya $25 \%$ yang kualitas tidurnya baik.

Hasil uji statistik chi-square didapatkan nilai $\mathrm{p}$ value $0,000 \leq 0,05$ berarti dapat disimpulkan berarti dapat disimpulkan ada perbedaan proporsi kualitas tidur responden yang mengalami tingkat kecemasan ringan dengan yang mengalami tingkat kecemasan sedang, artinya Ho ditolak dan $\mathrm{Ha}$ diterima (ada hubungan tingkat kecemasan dengan kualitas tidur penderita asma bronchial di Instalasi Rawat Inap RSUD Kabupaten Bintan Tahun 2019).

\section{PEMBAHASAN}

Berdasarkan hasil uji statistik chisquare didapatkan nilai $\mathrm{p}$ value $0,000 \leq 0,05$ berarti dapat disimpulkan berarti dapat disimpulkan ada perbedaan proporsi kualitas tidur responden yang mengalami tingkat kecemasan ringan dengan yang mengalami tingkat kecemasan sedang, artinya Ho ditolak dan $\mathrm{Ha}$ diterima (ada hubungan tingkat kecemasan dengan kualitas tidur penderita asma bronchial di Instalasi Rawat Inap RSUD Kabupaten Bintan Tahun 2019).

Secara keseluruhan hasil penelitian ini menunjukkan bahwa responden di Instalasi Rawat Inap RSUD Kabupaten Bintan memiliki kecemasan yang ringan dan mengalami perubahan kualitas tidur yang baik. Hal ini berarti kecemasan mempengaruhi kualitas tidur seorang pasien. Keadaan cemas atau stres yang dialami individu mempengaruhi kemampuan individu untuk tidur atau tetap tertidur. Penelitian sebelumnya menunjukkan bahwa tingkat stres sedang dan berat sangat lekat dengan jam tidur rendah dan berpengaruh dengan kejadian mimpi buruk dan gangguan tidur. Emosional dapat menimbulkan perasaan tegang dan putus asa pada individu, perasaan tersebut dapat menyebabkan individu sulit tidur atau sering terbangun saat tidur (Patricia A. Potter, 2015).

Pada penelitian ini menunjukkan bahwa adanya pengaruh antara semakin berat tingkat kecemasan semakin buruk kualitas tidurnya. Gangguan mental yang erat hubungannya dengan gangguan tidur adalah kecemasan. Adanya kecemasan dapat menyebabkan timbulnya gejala psikologis seperti Sulit berkonsentrasi, mudah lupa, pikiran kosong, merasa tegang dan gelisah, cepat marah, sensitif, tidak sabaran, kehilangan kepercayaan diri ,cenderung melakukan sesuatuberulang-ulang, dan kesulitan tidur (Maramis, 2015).

Hal ini juga sama dengan penelitian yang dilakukan oleh Sri Satiti Budayani (2015) tentang 
hubungan tingkat kecemasan dengan kualitas tidur pada pasien asma di RSUD Kabupaten Karanganyar Berdasarkan pengujian statistik dengan uji Spearman's rho, dinyatakan ada hubungan yang signifikan antara tingkat kecemasan dengan kualitas tidur pada pasien asma yang dirawat inap yang ditunjukan dengan nilai $p$ Value sebesar 0,00 atau kurang dari 0,05, pada taraf signifikan $95 \%$ sehingga hipotesis yang menyatakan bahwa ada hubungan antara tingkat kecemasan dan kualitas tidur pada pasien asma yang dirawat inap terbukti atau diterima. Keeratan hubungan antara kecemasan dan kualitas tidur bias ditunjukkan dengan nilai koefisien kontingensi dengan nilai 0,889 yang berarti hubungan itu sangat kuat.

Hal ini juga sama dengan penelitian Winda Purwaningsih (2014) Asma tidak terkontrol memiliki kualitas tidur buruk sebesar 14 responden (38,9\%), asma terkontrol sebagian yang memiliki kualitas tidur buruk sebanyak enam responden $(16,7 \%)$, terkontrol penuh dengan kualitas tidur buruk satu responden $(2,8 \%)$. Penderita asma yang memiliki kualitas tidur baik pada asma tidak terkontrol sebanyak enam responden $(16,7 \%)$, terkontrol sebagian lima responden $(13,8 \%)$, asma terkontrol penuh empat responden $(11,1 \%)$. Penelitian ini menggunakan uji fisher sebagai alternatif chi-square, didapatkan nilai $\mathrm{P}=0,042 \quad(<0,05)$, maka secara statistik dapat disimpulkan bahwa terdapat hubungan antara penyakit asma dengan kualitas tidur malam pada penderita asma umur 18-59 tahun di BBKPM Surakarta.

\section{KESIMPULAN DAN SARAN} KESIMPULAN
1. Tingkat kecemasan responden sebagian besar kecemasan ringan sebanyak 38 orang $(54,3 \%)$.

2. Kualitas tidur responden sebagian besar kulaitas tidur baik sebanyak 40 orang $(57,1 \%)$.

3. Hasil analisa didapatkan nilai $\mathrm{p}$ value $0,000 \leq 0,05$ berarti dapat disimpulkan berarti dapat disimpulkan ada perbedaan proporsi kualitas tidur responden yang mengalami tingkat kecemasan ringan dengan yang mengalami tingkat kecemasan sedang, artinya Ho ditolak dan $\mathrm{Ha}$ diterima (ada hubungan tingkat kecemasan dengan kualitas tidur penderita asma bronchial di Instalasi Rawat Inap RSUD Kabupaten Bintan Tahun 2019). Analisis keeratan hubungan dua variabel didapat $\mathrm{OR}=8,250$.

\section{SARAN}

1. Bagi Institusi Pendidikan

Institusi pendidikan dapat menggunakan hasil penelitian ini sebagai tambahan pengetahuan dan bahan referensi dalam upaya meningkatkan dan memperkaya kajian keperawatan tentang tingkat kecemasan serta kualitas tidur pasien asma.

2. Bagi Pelayanan Keperawatan

Pelayanan keperawatan tidak saja berfokus pada tindakan farmakologis, tetapi harus bisa menciptakan lingkungan yang nyaman terutama memberi batasan skat atau korden di ruang pasien dan memberi batasan waktu kunjung pasien agar pasien tidurnya tidak terganggu

3. Bagi Penelitian Selanjutnya

Hasil penelitian ini dapat dijadikan dasar untuk melakukan penelitian lanjutan, seperti: 
a. Melakukan penelitian serupa diharapkan menggunakan jumlah sampel yang lebih banyak sehingga bisa didapatkan gambaran yang lebih baik dari hasil analisa penelitiannya. Penelitian lanjutan dengan mencari efektifitas menggunakan dua kelompok (kontrol dan intervensi).

b. Melakukan penelitian lanjutan pada lansia dengan teknik yang berbeda.

c. Melakukan penelitian lanjutan tentang karakteristik responden seperti usia, jenis kelamin dan lainnya yang mempengaruhi kualitas tidur

DAFTAR PUSTAKA

Asrori, A. (2015). Terapi Kognitif Perilaku Untuk Mengatasi Gangguan Kecemasan Sosial. Jurnal Ilmiah Psikologi Terapan (JIPT).

Australian Institute of Health and Welfare 2015. (2015). Australia's welfare 2015. Australia's Welfare Series No. 12. Cat. No. AUS 189.

Berman, A., Snyder, S. J., \& Frandsen, G. (2016). Kozier and Erb's Fundamentals of Nursing Concepts, Process, and Practice Tenth Edition. In Kozier and Erb's Fundamentals of Nursing.

Budiawan, W., Prastawa, H., Kusumaningsari, A., \& Sari, D. N. (2016).Pengaruh Monoton, Kualitas Tidur, Psikofisiologi, Distraksi, Dan Kelelahan Kerja Terhadap Tingkat Kewaspadaan.J@Ti Undip : Jurnal Teknik Industri. https://doi.org/10.12777/jati.11.

\section{$1.37-44$}

Carpenito, L. J. (2018). Buku Saku Kedokteran. Jakarta. EGC.

Colby, L. A., \& Corwin, E. (2016). Occupational Health and Safety. https://doi.org/10.1016/B978-012-804010-2.00014-X

Dariah, E. D., \& Okatiranti. (2015). Hubungan Kecemasan Dengan Kualitas Tidur Lansia Di Posbindu Anyelir Kecamatan Cisarua Kabupaten Bandung Barat. Jurnal Ilmu Keperawatan.

Fauzan, A. D., Lailiyya, N., Esti Kusumandari, D., \& Yosef Suratman, F. (2019). Analisa Pengaruh Rangsangan Aromaterapi Lavender Dan Kayu Cendana Terhadap Kualitas Tidur Berbasiskan Gelombang Eeg. Tektrika Jurnal Penelitian Dan Pengembangan Telekomunikasi, Kendali, Komputer, Elektrik, Dan Elektronika. https://doi.org/10.25124/tektrika .v4i1.1608

Ferliani, F., Sundaru, H., Koesnoe, S., \& Shatri, H. (2017). Kepatuhan Berobat pada Pasien Asma Tidak Terkontrol dan Faktor-Faktor yang Berhubungan. Jurnal Penyakit Dalam Indonesia. https://doi.org/10.7454/jpdi.v2i3 .79

Gais, S., \& Schönauer, M. (2017). Untangling a Cholinergic Pathway from Wakefulness to Memory. Neuron. https://doi.org/10.1016/j.neuron. 
2017.05.010

GINA, C. científico de 1. (2016). Global Strategy for Asthma Management and Prevention ( 2016 update ). Guía Gina Actualización.

Global Initiative for Asthma. (2018). 2019 GINA Report: Global Strategy for Asthma Management and Prevention 2019. In Global Initiative for Asthma. https://doi.org/10.1002/uog.894 7

HALL, J. E., \& GUYTON, A. C. (2017). Guyton \& Hall: Tratado de Fisiologia médica. In Journal of Chemical Information and Modeling. https://doi.org/10.1017/CBO978 1107415324.004

Handayani, R. (2017). Faktor-Faktor Yang Berhubungan Dengan Tingkat Kecemasan Menjelang Persalinan Pada Ibu Primigravida Trimester III di Wilayah Kerja Puskesmas Lubuk Buaya Padang Tahun 2012. NERS Jurnal Keperawatan. https://doi.org/10.25077/njk.11. 1.60-69.2015

Hidayat, A. A. A., \& Uliyah, M. (2019). The effect of the nursing care model based on culture to improve the care of malnourished madurese children in Indonesia. Open Access Macedonian Journal of Medical Sciences. https://doi.org/10.3889/oamjms. 2019.260
Hidayat, S., \& Mumpuningtias, E. D. (2018). Terapi Kombinasi Sugesti Dan Dzikir Dalam Peningkatan Kualitas Tidur Pasien. Care: Jurnal Ilmiah Ilmu Kesehatar https://doi.org/10.33366/cr.v6i: 953

Julianti, H. P., Wahyudati, S., Kartadinata, R. T., Handoyo, R., $\&$ Noviolita. (2018). Efek latihan relaksasi otot progresif terhadap perbaikan gejala klinis, kecemasan, hasil elektromiografi dan kualitas hidup pasien spasmofilia. Media Medika Muda.

Kemenkes RI. (2018). Hasil Utama Riset Kesehatan Dasar Tahun 2018. Kementrian Kesehatan Republik Indonesia. https://doi.org/1 Desember 2013

Kobak, K. A., Greist, R., Jacobi, D. M., Levy-Mack, H., \& Greist, J. H. (2015). Computer-assisted cognitive behavior therapy for obsessive-compulsive disorder: A randomized trial on the impact of lay vs. professional coaching. Annals of General Psychiatry.

https://doi.org/10.1186/s12991015-0048-0

Kuswardani, K., Purnomo, D., \& Amanati, S. (2017). Pengaruh Nebulizer, Infra Red dan Chest Therapy terhadap Asma Bronchiale. Jurnal Fisioterapi Dan Rehabilitasi. https://doi.org/10.33660/jfrwhs. v1i1.10

Laksana, M. A., \& Berawi, K. N. (2015). Faktor - Faktor yang 
Berpengaruh pada Timbulnya Kejadian Sesak Napas Penderita Asma Bronkial. Majority.

Lindseth, G., Murray, A., \& Helland, B. (2015). Nutrition and sleep: An overview. In Nutraceuticals and Functional Foods in Human Health and Disease Prevention.

https://doi.org/10.1201/b19308

Mander, B. A., Winer, J. R., \& Walker, M. P. (2017). Sleep and Human Aging. Neuron. https://doi.org/10.1016/j.neuron. 2017.02.004

Maria, G., Beata, G., Chonlada, S., Maria, K., Golebiowska, M., Siripanich, C., ... Dick, A. S. (2017). Assessment of verbal working memory before and after surgery for low-grade glioma. Journal of NeuroOncology.

https://doi.org/10.5604/1730750 3.1213003

Mintarsih, W. (2017). Pendampingan Kelas Ibu Hamil Melalui Layanan Bimbingan Dan Konseling Islam Untuk Mengurangi Kecemasan Proses Persalinan. Sawwa: Jurnal Studi Gender.

https://doi.org/10.21580/sa.v12i 2.1545

Munardi, A. (2016). United States Counterterrorism on ISIS. Journal of Government and Politics. https://doi.org/10.18196/jgp.201 6.0027

Nursalam. (2017). Metodologi Penelitian Ilmu Keperawatan:
Pendekatan Praktis. Metodologi Penelitian Ilmu Keperawatan: Pendekatan Praktis.

Patricia A. Potter. Anne Griffin Perry. Patricia A. Stockert. Amy M. Hall. (2015). Fundamental Keperawatan ( $8^{\mathrm{a}}$ Ed.) Potter Perry. https://doi.org/978-849022-586-8

Priharyanti Wulandari, Dwi Retnaningsih, E. A. (2018). Pengaruh Prenatal Yoga Terhadap Tingkat Kecemasan Pada Ibu Primigravida Trimester Ii Dan Iii Di Studio Qita Yoga Kecamatan Semarang Selatan Indonesia. Journal Keperawatan.

Saputra, A. A., Rosyidah, I., \& W, A C. (2016). Asuhan Keperawatan Bersihan Jalan Napas Tidak Efektif Pada Ny "S" Dengan Asma (Laporan Kasus Di Ruang Cempaka Rsud Jombang). Jurnal Keperawatan.

Schroeder, F. (2015). Bringing practice closer to research seeking integrity, sincerity and authenticity. International Journal of Education Through Art.

https://doi.org/10.1386/eta.11.3. 343_1

Sherwood, V. (2015). Human Physiology From Cells to systems

https://doi.org/10.1128/mcb.009 92-14

Smeltzer, S. ., Bare, B. ., Hinkle, J. L., \& Cheever, K. . (2015). Handbook for Brunner and Suddarth's Textbook of 
Medical-Surgical Nursing. In Lippincott Williams \& Wilkins.

Sondakh, J. J., \& Yuliani, I. (2017).

Kecemasan Antara Primigravida dan Multigravida dalam Menghadapi Proses Persalian. Jurnal Pendidikan Kesehatan. https://doi.org/10.31290/jpk.v(6 )i(1)y(2017).page:1-4

Stuiver, M., Reimer, P. J., \& Reimer, R. . (2019). CALIB 7.1.

Sugiyono. (2016a). Metode Penelitian Kuantitatif, Kualitatif dan Kombinasi (Mixed Methods). Bandung: Alfabeta. https://doi.org/Doi 10.1016/J.Datak.2004.11.010

Sugiyono, P. D. metode penelitian kuantitatif, kualitatif,dan R\&D. , Alfabeta, cv. (2016).

Sujarweni, V. W. (2015). SPSS untuk Penelitian. In SPSS untuk Penelitian.

Sukorini, M. U. (2017). Hubungan Gangguan Kenyamanan Fisik Dan Penyakit Dengan Kualitas Tidur Ibu Hamil Trimester Iii. The Indonesian Journal of Public Health. https://doi.org/10.20473/ijph.v1 2i1.2017.1-12

Tsitsi, T., Charalambous, A., Papastavrou, E., \& Raftopoulos, V. (2017). Efektivitas intervensi relaksasi (relaksasi otot progresif dan teknik gambar yang dipandu) untuk mengurangi kecemasan dan meningkatkan suasana hati orang tua dari anak-anak yang dirawat di rumah sakit dengan keganasan . European Journal

of Oncology Nursing.

https://doi.org/10.1016/j.ejon.20

16.10.007

Wang, C., Yue, F., \& Kuang, S. (2017). Food allergies and asthma. Current opinion in allergy and clinical immunology, 11(3), pp.249-54. Available at: http://www.pubmedcentral.nih.g ov/articlerender.fcgi? artid=3155 248\&tool=pmcentrez\&renderty pe $=$ abstract.

Wartonah Dan Tarwoto. (2015). kebutuhan dasar manusia dan proses keperawatan. In Salemba medika.

https://doi.org/10.1039/c2dt321

91b

World Health Organization. (2016). World Health Statistics Monitoring Health For The SDGs. World Health Organization. https://doi.org/10.1017/CBO978 1107415324.004 
